University of Nebraska - Lincoln

DigitalCommons@University of Nebraska - Lincoln

USGS Staff -- Published Research

US Geological Survey

2012

\title{
Copper Pellets Simulating Oral Exposure to Copper Ammunition: Absence of Toxicity in American Kestrels (Falco sparverius)
}

\author{
J. Christian Franson \\ United States Geological Survey, jfranson@usgs.gov \\ Lesanna L. Lahner \\ United States Geological Survey \\ Carol U. Meteyer \\ United States Geological Survey \\ Barnett A. Rattner \\ United States Geological Survey, brattner@usgs.gov
}

Follow this and additional works at: http:// digitalcommons.unl.edu/usgsstaffpub

Part of the Geology Commons, Oceanography and Atmospheric Sciences and Meteorology Commons, Other Earth Sciences Commons, and the Other Environmental Sciences Commons

Franson, J. Christian; Lahner, Lesanna L.; Meteyer, Carol U.; and Rattner, Barnett A., "Copper Pellets Simulating Oral Exposure to Copper Ammunition: Absence of Toxicity in American Kestrels (Falco sparverius)" (2012). USGS Staff -- Published Research. 950. http:// digitalcommons.unl.edu/usgsstaffpub/950

This Article is brought to you for free and open access by the US Geological Survey at DigitalCommons@University of Nebraska - Lincoln. It has been accepted for inclusion in USGS Staff -- Published Research by an authorized administrator of DigitalCommons@University of Nebraska - Lincoln. 


\title{
Copper Pellets Simulating Oral Exposure to Copper Ammunition: Absence of Toxicity in American Kestrels (Falco sparverius)
}

\author{
J. Christian Franson - Lesanna L. Lahner • \\ Carol U. Meteyer • Barnett A. Rattner
}

Received: 14 February 2011/Accepted: 28 March 2011/Published online: 22 April 2011

(C) Springer Science+Business Media, LLC (outside the USA) 2011

This document is a U.S. government work and is not subject to copyright in the United States.

\begin{abstract}
To evaluate the potential toxicity of copper $(\mathrm{Cu})$ in raptors that may consume $\mathrm{Cu}$ bullets, shotgun pellets containing $\mathrm{Cu}$, or $\mathrm{Cu}$ fragments as they feed on wildlife carcasses, we studied the effects of metallic $\mathrm{Cu}$ exposure in a surrogate, the American kestrel (Falco sparverius). Sixteen kestrels were orally administered $5 \mathrm{mg} \mathrm{Cu} / \mathrm{g}$ body mass in the form of $\mathrm{Cu}$ pellets (1.18-2.00 $\mathrm{mm}$ in diameter) nine times during 38 days and 10 controls were sham gavaged on the same schedule. With one exception, all birds retained the pellets for at least $1 \mathrm{~h}$, but most $(69 \%)$ regurgitated pellets during a 12-h monitoring period. Hepatic $\mathrm{Cu}$ concentrations were greater in kestrels administered $\mathrm{Cu}$ than in controls, but there was no difference in $\mathrm{Cu}$ concentrations in the blood between treated and control birds. Concentration of the metalbinding protein metallothionein was greater in male birds that received $\mathrm{Cu}$ than in controls, whereas concentrations in female birds that received $\mathrm{Cu}$ were similar to control female birds. Hepatic $\mathrm{Cu}$ and metallothionein concentrations in kestrels were significantly correlated. Histopathologic alterations were noted in the pancreas of four treated kestrels and two controls, but these changes were not associated with hepatic or renal $\mathrm{Cu}$ concentrations, and no lesions were seen in other tissues. No clinical signs were observed, and there was no treatment effect on body mass; concentrations of $\mathrm{Cu}$, hemoglobin, or methemoglobin in the blood; or $\mathrm{Cu}$ concentrations in kidney, plasma
\end{abstract}

J. Christian Franson $(\bowtie) \cdot$ L. L. Lahner · C. U. Meteyer United States Geological Survey, National Wildlife Health Center, Madison, WI 53711, USA

e-mail: jfranson@usgs.gov

B. A. Rattner

United States Geological Survey, Patuxent Wildlife Research Center, Beltsville, MD 20705, USA biochemistries, or hematocrit. Based on the parameters we measured, ingested $\mathrm{Cu}$ pellets pose little threat to American kestrels (and presumably phylogenetically related species), although the retention time of pellets in the stomach was of relatively short duration. Birds expected to regurgitate $\mathrm{Cu}$ fragments with a frequency similar to kestrels are not likely to be adversely affected by $\mathrm{Cu}$ ingestion, but the results of our study do not completely rule out the potential for toxicity in species that might retain $\mathrm{Cu}$ fragments for a longer time.

Lead poisoning from ingested lead shotgun pellets was first reported in birds in the late 1800s (Friend et al. 2009). Although documented in waterfowl for many years, the ingestion of lead and/or poisoning, based on lead residues in tissues, has also been reported in at least 58 species of free-ranging terrestrial birds from throughout the world, including 28 raptors (Pain et al. 2009). A nationwide ban on the use of lead shotgun pellets for hunting waterfowl and American coots (Fulica americana) was instituted in the United States in 1991, primarily because of lead poisoning in waterfowl and in eagles that fed on waterfowl carcasses containing ingested or embedded lead shot (Friend et al. 2009). Although some states have implemented additional restrictions, lead ammunition is often still used for hunting upland game, large game animals, and animals that are considered pests, potentially exposing scavengers that feed on unretrieved carcasses or offal left in the field to lead shotgun pellets or lead rifle bullets and their fragments (Rattner et al. 2008). In a study with deer killed with lead-based bullets, radiography showed averages of 160 and 551 metal fragments, respectively, in offal piles and entire carcasses, with clusters of fragments radiating from an average of $7 \mathrm{~cm}$ to a maximum of $15 \mathrm{~cm}$ 
from wound channels (Hunt et al. 2006). In another study of deer shot with lead ammunition, radiography showed an average of 180 metal fragments in the viscera and 356 fragments in carcasses (Knott et al. 2010). Lead exposure and poisoning associated specifically with ingested rifle bullet fragments has been reported in free-ranging raptors, including the white-tailed sea eagle (Haliaeetus albicilla), Steller's sea eagle (H. pelagicus), bald eagle (H. leucocephalus), golden eagle (Aquila chrysaetos), and California condor (Gymnogyps californianus) (Wiemeyer et al. 1988; Craig et al. 1990; Gill and Langelier 1994; Iwata et al. 2000; Helander et al. 2009). Furthermore, evidence of greater lead exposure during hunting versus nonhunting seasons has been noted in several species of predatory and scavenging birds, including the California condor (Pain et al. 1997; Hunt et al. 2007; Craighead and Bedrosian 2008; Neumann 2009).

Andean condors (Vultur gryphus), an experimental surrogate for California condors, were found to be quite sensitive to lead poisoning, exhibiting retention of administered lead shot and rapid dissolution and absorption of lead, leading to quick onset of poisoning (Pattee et al. 2006). Lead poisoning from ingested lead ammunition was first reported in the California condor in the 1980s (Wiemeyer et al. 1988). In 2005, the Arizona Game and Fish Department began offering nonlead ammunition to big-game hunters in an effort to decrease lead exposure in California condors, and in 2008 regulations were instituted in California restricting the use of lead ammunition in the range of the California condor in the central and southern part of the state (Arizona Game and Fish Department 2009; Avery and Watson 2009). Copper ( $\mathrm{Cu}$ ) has been reported to be a comparable alternative to lead for rifle bullets, and $\mathrm{Cu}$ bullets tend not to fragment as lead bullets do (Hunt et al. 2006; Knott et al. 2009). Steel is generally the preferred nontoxic alternative to lead for shotgun pellets (Oltrogge 2009). Of the 11 other alternatives approved by 2009, only two contain $\mathrm{Cu}$, one with $44 \% \mathrm{Cu}$ and one with 9 to $16 \%$ $\mathrm{Cu}$, although $\mathrm{Cu}$ coatings on approved nontoxic shot types are also allowed (United States Fish and Wildlife Service 2009).

At least one experimental study of $\mathrm{Cu}$ exposure has been conducted with raptors, in which turkey vultures (Cathartes aura) were fed $\mathrm{Cu}$ pellets in food items (Risebrough et al. 2001). During the 8.5-week study, birds were radiographed weekly and administered additional pellets to sustain the original dosage of $2.3 \mathrm{gm} \mathrm{Cu} / \mathrm{kg}$ body mass. At the end of the study, $\mathrm{Cu}$ concentrations were somewhat greater in livers of treated birds versus controls, but concentrations in blood were similar, and no effects were noted on body mass, hematology, plasma biochemistries, or histopathology (Risebrough et al. 2001). Previous studies of $\mathrm{Cu}$ pellet exposure in mallards (Anas platyrhynchos) and Pekin ducks have shown no toxic effects (Bellrose 1965; Irby et al. 1967; Locke et al. 1967; Krone et al. 2009). Thomas and McGill (2008) studied the dissolution of $\mathrm{Cu}$ from tungsten-bronze pellets containing $44 \% \mathrm{Cu}$ in a simulated avian gizzard and concluded that the amount released would not pose a toxic risk if wild birds ingested the pellets.

In contrast to the negative results of experimental studies of metallic $\mathrm{Cu}$ in mallards and vultures, mortality has been reported in captive Canada geese (Branta canadensis), which began to die within hours after a pond was treated with $\mathrm{Cu}$ sulfate used as an algicide (Henderson and Winterfield 1975). The deaths of several free-ranging mute swans (Cygnus olor) were attributed to $\mathrm{Cu}$ poisoning of undetermined source (Kobayashi et al. 1992). Some groups of animals, particularly ruminants, are more sensitive to increased dietary $\mathrm{Cu}$ exposure than others and may develop clinical pathologies, such as enzymatic indications of liver damage, hemoglobinemia, and methemoglobinemia, sometimes resulting in death (National Research Council 1977). Domestic poultry are more resistant to $\mathrm{Cu}$ toxicity than mammals, but studies have shown decreased weight gain, weakness, anorexia, lethargy, and anemia in chickens (Gallus domesticus) exposed to $\mathrm{Cu}$ salts (National Research Council 1977). Metallothionein synthesis can be induced by various metals, including $\mathrm{Cu}$, and significant correlations between metallothionein and $\mathrm{Cu}$ concentrations in liver have been reported in some species of wild birds (Dunn et al. 1987; Kojadinovic et al. 2007).

Because most types of nontoxic shot approved for waterfowl hunting do not contain $\mathrm{Cu}$, exposure of avian predators or scavengers to metallic $\mathrm{Cu}$ when feeding on wildlife carcasses or offal is more likely to result from ingesting $\mathrm{Cu}$ bullets made entirely of $\mathrm{Cu}$ than shotgun pellets containing some fraction of $\mathrm{Cu}$. Because published information on $\mathrm{Cu}$ toxicity in avian wildlife, particularly raptors, is limited, we evaluated metallic $\mathrm{Cu}$ exposure in American kestrels (Falco sparverius), a surrogate often used as a model for other raptors, particularly in toxicology studies (Eisler 2000; Bardo and Bird 2009). Using orally administered $\mathrm{Cu}$ pellets, we studied the effects of $\mathrm{Cu}$ exposure on survival, clinical signs, body mass, $\mathrm{Cu}$ concentrations in tissues, biochemical markers in tissues, and histopathology in kestrels.

\section{Materials and Methods}

Birds, Husbandry, and $\mathrm{Cu}$ Administration

Twenty-six captive-bred, 1-year-old American kestrels were housed individually in outdoor flight pens $(6 \times 2.4 \times 2.4 \mathrm{~m})$ at the Patuxent Wildlife Research 
Center in Laurel, MD. Each pen included a covered perch box, exposed rope perch, water bowl, and covered feeding tray. Birds were fed $50 \mathrm{~g}$ of a bird of prey diet $(3.3 \mathrm{mg} / \mathrm{kg}$ $\mathrm{Cu}$ as fed; Nebraska Brand, North Platte, NE) once daily and two mice (Mus musculus; Charles River Laboratories, Frederick, MD) approximately once weekly. Uneaten food was removed before the next feeding.

Kestrels were administered $\mathrm{Cu}$ pellets $(99.9 \% \mathrm{Cu}$; Fisher Scientific, Pittsburgh, PA) nine times during the study at the rate of $5 \mathrm{mg} \mathrm{Cu} / \mathrm{g}$ body mass by way of oral gavage tube. The pellets were spherical in shape, and the size range included those that passed through a no. 10 (2.00-mm mesh) soil sieve but not through a no. 16 (1.18$\mathrm{mm}$ mesh) sieve. Thus, the approximate diameter of $\mathrm{Cu}$ pellets used in the study ranged from $>1.18$ to $<2.00 \mathrm{~mm}$, with a surface area $>4.37 \mathrm{~mm}^{2}$ but $<12.6 \mathrm{~mm}^{2}$. Kestrels were fed mice several days after dosing to minimize the effect that regurgitation of fur and bones might have on $\mathrm{Cu}$ pellet retention (Ford 2010). The dose exceeded the amount calculated based on a $1.2-\mathrm{kg}$ red-tailed hawk (Buteo jamaicensis) consuming a .22-caliber solid $\mathrm{Cu}$ bullet (e.g., Barnes Bullets, Mona, UT) and a 8.5-kg California condor consuming a .270-caliber solid $\mathrm{Cu}$ bullet, resulting in total estimated $\mathrm{Cu}$ exposures of 4.1 and $1.14 \mathrm{mg} / \mathrm{g}$ body mass, respectively. The use of small $\mathrm{Cu}$ pellets allowed for accurate dosing and resulted in a relatively large combined surface area, thus providing for greater erosion in the stomach and subsequent absorption of $\mathrm{Cu}$ compared with a single pellet of the same mass. Clear plastic flexible tubing, $5 \mathrm{~mm}$ in diameter with a 3-mm internal diameter, was passed distal to the crop; $\mathrm{Cu}$ pellets were delivered through a funnel; and a metal stylet was passed to the end of the tube to expel any pellets remaining in the tubing into the upper gastrointestinal tract. Control birds were sham gavaged. Each day before being dosed, kestrels were weighed for dose calculation. After being fasted overnight, birds typically received approximately 17-22 pellets/day on days $0,12,14,16,29$, $31,33,35$, and 37. Immediately after dosing, each kestrel was placed in a stainless steel cage $(23 \times 33 \times 38 \mathrm{~cm})$ for $1 \mathrm{~h}$ for observation and to detect regurgitation of $\mathrm{Cu}$ pellets and were fed the bird of prey diet $1 \mathrm{~h}$ after release into the large pen. The only exception was that on day 12 birds were held in the small cages overnight $(12 \mathrm{~h})$ to detect regurgitation and were fed after release the next morning. In addition to being weighed on the day before dosing, all kestrels were weighed at weekly intervals. Each bird was monitored by visual inspection for a minimum of $10 \mathrm{~min}$ twice daily for the occurrence of clinical signs, such as lethargy, ataxia, or anorexia. Once during the study, each dosed kestrel was radiographed $48 \mathrm{~h}$ after $\mathrm{Cu}$ administration. In addition, three dosed birds were radiographed $24 \mathrm{~h}$ after dosing.
Blood Collection, Hematology, and Plasma Biochemistries

Blood samples were collected from all kestrels by way of jugular venipuncture on days $1,8,17,27$, and at the end of the study, when controls were bled on day 37 and dosed birds were bled on day 38. Blood was placed in heparinized tubes, and the hematocrit was measured on each sampling day. Methemoglobin was measured on days 1, 17, and at the end of the study, and hemoglobin concentration was measured at the end of the study. A portion of the heparinized blood sample collected at the end of the study was centrifuged and the plasma collected and stored in a liquid nitrogen vapor shipper at $-150^{\circ} \mathrm{C}$, transported to the laboratory, and held at $-80^{\circ} \mathrm{C}$ for biochemistry analysis. A portion of each whole blood sample collected on days 1 , 17 , and at the end of the study were placed in the vapor shipper and transferred to the laboratory, where they were stored at $-20^{\circ} \mathrm{C}$ for subsequent $\mathrm{Cu}$ analysis.

The hemoglobin concentration in fresh whole blood was determined as cyanomethemoglobin using a commercially available Drabkin reagent and a hemoglobin reference standard (Pointe Scientific, Canton, MI). Duplicate American kestrel whole-blood samples $(10 \mu \mathrm{l})$ were each vortex mixed in $2 \mathrm{ml}$ Drabkin reagent and incubated at $4^{\circ} \mathrm{C}$ until analysis. All samples were analyzed on the same day, 6 days after blood was collected from controls and 5 days after blood was collected from dosed birds. A hemoglobin standard was prepared in distilled water and mixed with Drabkin reagent to achieve final concentrations of 2.88, 5.75, 11.50, 17.25, and 23.0 g/dl. Absorbance of samples and standards was determined at $540 \mathrm{~nm}$ with a Beckman DU640 spectrophotometer (Beckman Instruments, Fullerton, CA). A standard curve was generated by linear regression, and kestrel whole-blood hemoglobin concentration was interpolated from the curve. Methemoglobin concentration in fresh whole blood was determined as the change in absorbance after the addition of cyanide, which converts methemoglobin to cyanomethhemoglobin (Fairbanks and Klee 1987). Briefly, $100 \mu$ l whole blood was added to $3.9 \mathrm{ml}$ distilled water and vortex mixed, then an equal volume of $0.15 \mathrm{M}$ potassium phosphate buffer ( $\mathrm{pH}$ 6.6) was added to the hemolysate. The absorbance difference between the blank cuvette (hemolysate only) and a sample cuvette (hemolysate plus potassium ferrocyanide) was determined at $630 \mathrm{~nm}$. Potassium cyanide was then added to both cuvettes, and the absorbance was again determined at $630 \mathrm{~nm}$. Methemoglobin was calculated as the ratio of these absorbance differences and expressed as percent total hemoglobin. Analysis of biochemistries, including glucose, aspartate aminotransferase, alkaline phosphatase, creatine kinase, cholesterol, triglycerides, total protein, albumin, calcium, uric acid, nonesterified 
fatty acids, and beta-hydroxybutyrate, was performed by Marshfield Labs Veterinary Services (Marshfield, WI) in plasma collected at the end of the study.

\section{Necropsy, Tissue Collection, and Histopathology}

Control and dosed kestrels were euthanized on days 37 and 38 , respectively, with an intravenous injection of a pentobarbital sodium and phenytoin sodium solution (Beuthanasia-D Special; Intervet Schering-Plough Animal Health, Boxmeer, The Netherlands), and necropsies were completed within $30 \mathrm{~min}$. Pieces of liver, kidney with gonad and adrenal, spleen, stomach, duodenum with pancreas, junction of the small and large intestine and cecae, and bursa of Fabricius were fixed in 10\% buffered formalin, sectioned at $4 \mu \mathrm{m}$, and stained with hematoxylin-eosin (HE) for histopathologic examination with light microscopy. Liver for $\mathrm{Cu}$ and metallothionein analysis, and kidney for $\mathrm{Cu}$ analysis, were frozen at $-20^{\circ} \mathrm{C}$.

\section{$\mathrm{Cu}$ and Metallothionein Analysis}

Liver and kidney samples (approximately $0.75 \mathrm{~g}$ ) were dried overnight at $105^{\circ} \mathrm{C}$ and combined with $5 \mathrm{ml}$ nitric acid. Whole-blood samples (approximately $0.3 \mathrm{~g}$ ) were combined with $2 \mathrm{ml}$ nitric acid. Samples were prepared for analysis by pressure-controlled microwave digestion (MDS 2000; CEM, Matthews, $\mathrm{NC}$ ). $\mathrm{Cu}$ analysis was performed by flame atomic absorption spectroscopy (liver and kidney) or graphite furnace atomic absorption spectroscopy (blood) (Thermo Elemental M6 Solaar; Thermo, Franklin, MA) at a wavelength of $324.8 \mathrm{~nm}$ with Zeeman background correction. The lower limit of detection was $0.25 \mu \mathrm{g} / \mathrm{g}$ dry weight ( $\mathrm{dw}$ ) for liver and kidney and $0.02 \mu \mathrm{g} / \mathrm{g}$ wet weight (ww) for blood. Average recovery from spiked samples and standard reference materials (DOLT 3; National Research Council Canada) was $102 \%$. Results are expressed as $\mu \mathrm{g} / \mathrm{g} \mathrm{dw}$ for liver and kidney and $\mu \mathrm{g} / \mathrm{g}$ ww for blood. Moisture content of liver and kidney tissue was 68.5 and $75.6 \%$, respectively. Metallothionein concentration of liver was measured according to the silver saturation assay of Scheuhammer and Cherian (1991), with the exception that samples were subjected to an additional hemolysate, heating, and centrifugation step. Metallothionein concentrations are given in $\mu \mathrm{g} / \mathrm{g}$ ww.

\section{Statistics}

For each parameter that was measured multiple times during the course of the experiment (body mass, PCV, $\mathrm{MetHb}$, and blood $\mathrm{Cu}$ ), we performed repeated measures analysis of variance (ANOVA) on rank-transformed data and evaluated the time $\times$ treatment interaction term for significance to determine if responses of the sham-dosed controls and $\mathrm{Cu}$-dosed kestrels differed through time. For the parameters measured only at the end of the experiment (plasma biochemistries, liver metallothionein, hemoglobin, and $\mathrm{Cu}$ concentration in liver and kidney), factorial analysis of variance on rank-transformed data was used to evaluate treatment and sex effects and sex $\times$ treatment interaction. Among $\mathrm{Cu}$ concentrations in liver tissue of control kestrels, there was one outlier $(58.9 \mu \mathrm{g} / \mathrm{g} \mathrm{dw})$. We excluded this value from the study based on Dixon's test, where $Q_{\text {calculated }}(0.885)>Q_{\text {table }}(0.568)$ at the $99 \%$ confidence level (Rorabacher 1991). We evaluated the correlation between metallothionein and $\mathrm{Cu}$ in the liver with the Spearman rank correlation procedure. The Wilcoxon twosample test was used to compare $\mathrm{Cu}$ concentrations in liver and kidney of kestrels that exhibited microscopic pancreatic changes with those that did not. SAS software (SAS, Cary, NC) was used for all statistical analysis, and $\alpha=0.05$ was considered significant.

\section{Results}

\section{Pellet Retention and Body Mass}

During the 12-h monitoring period after $\mathrm{Cu}$ pellet administration on day 12,11 of 16 dosed kestrels regurgitated stomach contents containing an average of 18 pellets. Eight of ten control birds regurgitated stomach contents during the same period. On each of the other days that $\mathrm{Cu}$ pellets were administered (i.e., days $0,14,16,29,31,33$, 35, and 37), all birds retained the pellets for at least $1 \mathrm{~h}$, except one bird on day 0 . The three dosed kestrels that were radiographed at $24 \mathrm{~h}$ after dosing had 1,3 , and $4 \mathrm{Cu}$ pellets in the proventricular/ventricular region. Three of the 16 dosed kestrels that were radiographed at $48 \mathrm{~h}$ after dosing had retained 1-2 $\mathrm{Cu}$ pellets in the proventricular/ventricular area. No treatment effect was noted on body mass during the study, and no behavioral changes or clinical signs suggestive of toxicity were observed.

Hematology, Blood Cu, Plasma Biochemistries, Necropsy, and Histopathology

In treated birds and controls, mean hematocrit during the five sampling times varied from $40-42 \%$ and $39-42 \%$, respectively, and mean hemoglobin concentrations at the end of the study were 10.3 and $9.9 \mathrm{~g} / \mathrm{dl}$, respectively; there was no treatment effect on either variable. $\mathrm{Cu}$ exposure did not affect $\mathrm{Cu}$ or methemoglobin concentrations in blood (Table 1), and there was no treatment effect on any of the plasma biochemistries (Table 2). At necropsy, both the $\mathrm{Cu}$-treated and control birds were in good body condition with adequate fat reserves. Nine of the 16 treated kestrels, 
Table 1 Mean (SE) Cu concentration ( $\mu \mathrm{g} / \mathrm{g} w w)$ and methemoglobin (as \% of total hemoglobin) in the blood of $\mathrm{Cu}$-dosed and control kestrels

\begin{tabular}{llll}
\hline $\mathrm{Cu}$ and methemoglobin & Day 1 & Day 17 & $\begin{array}{l}\text { End of } \\
\text { study }^{\mathrm{a}}\end{array}$ \\
\hline $\mathrm{Cu}^{\mathrm{b}}$ & & & \\
$\quad$ Control & $0.28(0.02)$ & $0.28(0.02)$ & $0.31(0.02)$ \\
$\quad \begin{array}{l}\text { Cu-treated } \\
\text { Methemoglobin }\end{array}$ & $0.31(0.01)$ & $0.34(0.04)$ & $0.30(0.01)$ \\
$\quad \begin{array}{l}\mathrm{c} \\
\text { Control }\end{array}$ & $7.8(0.55)$ & $9.1(1.26)$ & $5.4(0.89)$ \\
Cu-treated & $7.2(0.68)$ & $8.4(0.81)$ & $6.1(0.59)$ \\
\hline
\end{tabular}

${ }^{a}$ Day 37 for controls, day 38 for Cu-treated kestrels

${ }^{\mathrm{b}} n=16$ for $\mathrm{Cu}$-treated kestrels; $n=10$ for control kestrels

c $n=13$ on day $1, n=14$ on day 17 , and $n=16$ on Day 38 for Cu-treated kestrels; $n=10$ each day for control kestrels

which had been administered $\mathrm{Cu} 24 \mathrm{~h}$ before they were euthanized, had $\mathrm{Cu}$ pellets (average 5 [range 1-11]) in the ventriculus. One bird had $1 \mathrm{Cu}$ pellet in the proximal duodenum. The lining of the ventriculus ranged from light yellow to green in all treated and control birds except for 1 $\mathrm{Cu}$-treated bird that had a light pink ventricular lining. No gross lesions indicative of toxicity were noted. Microscopic evaluation of tissues showed apoptosis (cell death without inflammation) and vacuolation of acinar cells (exocrine gland cells) in the pancreas (Fig. 1) of 4 of 16 kestrels that received $\mathrm{Cu}$ and 2 of 10 controls, 1 of which was the individual with the outlying hepatic $\mathrm{Cu}$ concentration of $58.9 \mu \mathrm{g} / \mathrm{g} \mathrm{dw}$. Mean Cu concentrations in liver $(26.6 \mu \mathrm{g} / \mathrm{g}$ $\mathrm{dw})$ and kidney $(12.4 \mu \mathrm{g} / \mathrm{g} \mathrm{dw})$ of kestrels with pancreatic changes were not significantly different $(p=0.810$ for liver; $p=0.952$ for kidney) from those without pancreatic changes (liver $=22.4 \mu \mathrm{g} / \mathrm{g} \mathrm{dw}$; kidney $=12.2 \mu \mathrm{g} / \mathrm{g} \mathrm{dw}$ ). No histopathologic lesions were noted in other tissues examined.

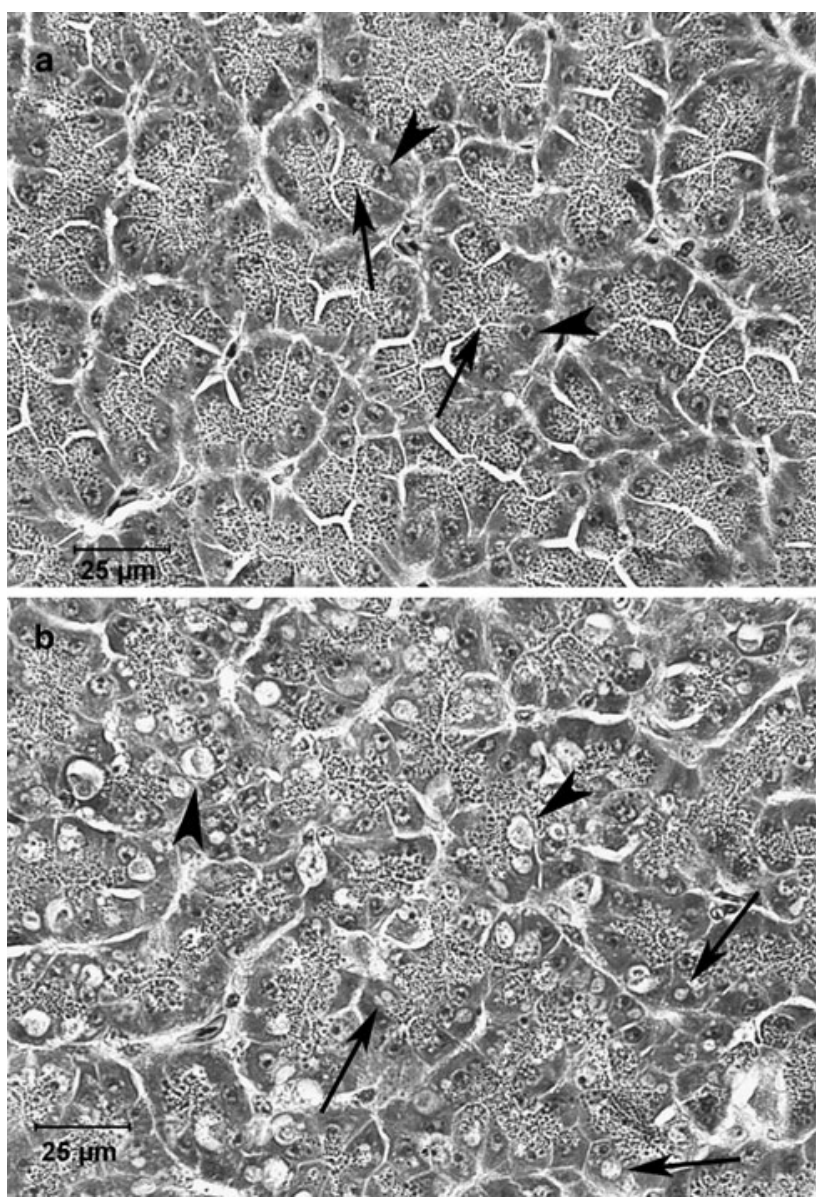

Fig. 1 Histologic sections of pancreas from 1-year-old female kestrels, trimmed $4-\mu \mathrm{m}$ thick, and stained with HE. a Normal pancreas from kestrel not exposed to $\mathrm{Cu}$ pellets with liver $\mathrm{Cu}$ residue of $17.0 \mu \mathrm{g} / \mathrm{g} \mathrm{dw}$. Note the distinct nuclei of acinar cells (arrowheads) and abundant zymogen granules in the cytoplasm (arrows). b Abnormal pancreas from kestrel administered $\mathrm{Cu}$ pellets with liver $\mathrm{Cu}$ residue of $20.7 \mu \mathrm{g} / \mathrm{g} \mathrm{dw}$. Cells have vacuolated cytoplasm (arrows) and apoptosis; cell death without inflammation (arrowheads)
Table 2 Mean (SE) of biochemistries in plasma of $\mathrm{Cu}$ treated and control kestrels

\begin{tabular}{lcc}
\hline Biochemistry & Control $(n=10)$ & Cu-treated $(n=16)$ \\
\hline Glucose (mg/dl) & $398(10)$ & $368(8.4)$ \\
Aspartate aminotransferase (IU/l) & $62(3.7)$ & $69(4.8)$ \\
Alkaline phosphatase (IU/l) & $202(13)$ & $180(8.9)$ \\
Creatine kinase (IU/l) & $855(42)$ & $1098(88)$ \\
Cholesterol (mg/dl) & $151(9.1)$ & $166(4.4)$ \\
Triglycerides $(\mathrm{mg} / \mathrm{dl})$ & $81(6.7)$ & $89(5.7)$ \\
Total protein $(\mathrm{g} / \mathrm{dl})$ & $2.17(0.1)$ & $2.20(0.1)$ \\
Albumin $(\mathrm{g} / \mathrm{dl})$ & $0.85(0.03)$ & $0.84(0.03)$ \\
Calcium $(\mathrm{mg} / \mathrm{dl})$ & $8.03(0.12)$ & $7.96(0.11)$ \\
Uric acid $(\mathrm{mg} / \mathrm{dl})$ & $9.8(1.5)$ & $8.8(1.0)$ \\
Nonesterified fatty acids $(\mathrm{meq} / \mathrm{l})$ & $0.29(0.04)$ & $0.27(0.02)$ \\
Beta-hydroxybutyrate $(\mathrm{mg} / \mathrm{dl})$ & $13.2(0.83)$ & $14.8(1.0)$ \\
\hline
\end{tabular}


$\mathrm{Cu}$ and Metallothionein Concentrations in Liver and $\mathrm{Cu}$ Concentrations in Kidney

A significant treatment effect, driven primarily by greater levels in male birds, and sex effect occurred in hepatic $\mathrm{Cu}$ concentrations of kestrels (Table 3 ). The mean concentration of $\mathrm{Cu}$ in livers of birds administered $\mathrm{Cu}$ was $26.9 \mu \mathrm{g} / \mathrm{g}$ $\mathrm{dw}$ in male and $20.7 \mu \mathrm{g} / \mathrm{g} \mathrm{dw}$ in female birds, whereas control birds had hepatic concentrations $<20 \mu \mathrm{g} / \mathrm{g} \mathrm{dw}$ (Table 3). Metallothionein concentrations in liver differed by treatment, but not sex, and there was a significant sex $\times$ treatment interaction (Table 3 ). Thus, the metallothionein concentration in treated male birds was nearly four times the concentration in control male birds, but in female birds the concentrations in livers of treated and control birds were similar (Table 3). Metallothionein and $\mathrm{Cu}$ concentrations in liver tissue were significantly correlated (Spearman $r=0.50, p=0.010$ ). $\mathrm{Cu}$ concentrations in kidney tissue did not differ by treatment or sex (Table 3).

\section{Discussion}

Although $\mathrm{Cu}$ concentrations in livers of American kestrels differed by treatment, the magnitude of the difference was small, and there was no difference in $\mathrm{Cu}$ concentrations in the blood between kestrels administered $\mathrm{Cu}$ and control birds. Furthermore, renal $\mathrm{Cu}$ concentration, body mass, and blood biochemistries were not affected by $\mathrm{Cu}$ exposure, and we observed no behavioral changes or clinical signs of toxicity. Similarly, toxicity was not observed in a study with turkey vultures administered $\mathrm{Cu}$ pellets (Risebrough et al. 2001). The $\mathrm{Cu}$ introduced into the stomach of kestrels (5 mg/g body weight) was approximately twice that $(2.3 \mathrm{~g} /$ $\mathrm{kg}$ ) used in the vulture study, and the pellets were

Table 3 Mean (SE) Cu concentration in liver and kidney $(\mu \mathrm{g} / \mathrm{g} \mathrm{dw})$ and metallothionein concentration $(\mu \mathrm{g} / \mathrm{g}$ ww) in liver of $\mathrm{Cu}$-treated and control kestrels

\begin{tabular}{lcl}
\hline $\mathrm{Cu}$ and metallothionein & Control $(n=10)$ & Cu-treated $(n=16)$ \\
\hline${\text { Liver } \mathrm{Cu}^{\mathrm{a}}}$ & $19.2(0.8)$ & $26.9(1.7)$ \\
$\quad$ Male & $18.0^{\mathrm{b}}(0.4)$ & $20.7(1.4)$ \\
$\quad$ Female & & \\
Liver metallothionein $^{\mathrm{c}}$ & & \\
$\quad$ Male & $11.6(1.6)$ & $42.1(8.4)$ \\
Female & $30.6(10.4)$ & $31.4(5.5)$ \\
Kidney $\mathrm{Cu}$ & $12.6(0.4)$ & $12.0(0.2)$ \\
\hline
\end{tabular}

${ }^{a}$ Significant treatment effect $(p \leq 0.001)$ and sex effect $(p=0.007)$ in factorial ANOVA

b One outlier, $58.9 \mu \mathrm{g} / \mathrm{g} \mathrm{dw}$, not included in this mean

c Significant treatment effect $(p=0.008)$ and sex $\times$ treatment interaction $(p=0.015)$ in factorial ANOVA administered to kestrels nine times during the course of the 37-day experiment, whereas vultures received pellets weekly during the 8.5-week study (Risebrough et al. 2001). Thus, both the mass of $\mathrm{Cu}$ (per unit of body mass) and the frequency of pellet administration were greater in our study, but the kestrels probably retained $\mathrm{Cu}$ for a shorter time than turkey vultures. During a 12-h monitoring period, $69 \%$ of kestrels regurgitated pellets and when radiographed $48 \mathrm{~h}$ after $\mathrm{Cu}$ administration only $19 \%$ of kestrels retained one or more pellets. $\mathrm{Cu}$ pellet retention in the vulture experiment was described as highly variable, but in a preliminary trial with six individuals, some pellets were still in the intestines of one or more vultures after 3 weeks (Risebrough et al. 2001).

Reports in mallards and other avian species also indicate that birds are quite tolerant to metallic $\mathrm{Cu}$. In an early experimental study, mallards administered $\mathrm{Cu}$ pellets $\leq 13 \mathrm{~g}$ exhibited transient weight loss but no mortality (Bellrose 1965). Another study reported that 1 of 24 mallards receiving 8 no. $6 \mathrm{Cu}$ pellets died, but the death could not be attributed to $\mathrm{Cu}$ toxicity, and no histopathological lesions were found in tissues of 4 ducks receiving $\mathrm{Cu}$ pellets (Irby et al. 1967; Locke et al. 1967). In a 24-day test with mallards that received 2-8 Cu-plated steel shot, none of the shot were voided by the ducks; no changes in body mass or hematocrit were noted; and histologic examination of tissues showed no lesions of $\mathrm{Cu}$ toxicosis (United States Fish and Wildlife Service, unpublished data). In a recent study, Pekin ducks were administered $6 \mathrm{Cu}$ pellets, each approximately $3 \mathrm{~mm}$ in diameter and weighing $148 \mathrm{mg}$, and the birds were killed 4 weeks later (Krone et al. 2009). No ducks died; $\mathrm{Cu}$ did not affect body weight; and no treatment-related lesions were noted in organs (Krone et al. 2009). $\mathrm{Cu}$ concentrations in liver and kidney tissue of Pekin ducks were approximately 100 and $10 \mu \mathrm{g} / \mathrm{g}$ ww, respectively (Krone et al. 2009). Calculated on a ww basis, $\mathrm{Cu}$ concentrations in liver and kidney of kestrels in our study were much lower at 7.5 and $2.9 \mu \mathrm{g} / \mathrm{g}$, respectively. Thomas and McGill (2008) studied the release of $\mathrm{Cu}$, tin, and iron from tungsten-bronze pellets (44.4\% $\mathrm{Cu}$ by mass) in vitro in a simulated avian gizzard at $\mathrm{pH} 2.0$. $\mathrm{Cu}$ was released at the rate of $43.17 \mathrm{mg} / \mathrm{d}$ from 8 tungsten-bronze pellets, and the investigators concluded that although this level exceeded daily $\mathrm{Cu}$ requirements of domestic birds, it was lower than levels known to cause toxicity. Pigeons (Columba livia) that were dosed daily for 14 days with soil from a small-arms firing range containing lead and $\mathrm{Cu}$ had increased lead, but not $\mathrm{Cu}$, concentrations in tissues (Bannon et al. 2011). However, the maximum daily dosage of $\mathrm{Cu}$ used in pigeons (approximately $0.002 \mathrm{mg} / \mathrm{g}$ body mass) was much less than the amount of $\mathrm{Cu}$ administered to kestrels ( $5 \mathrm{mg} / \mathrm{g}$ ) each of 9 times during our 38-day study. 
$\mathrm{Cu}$ is an essential trace element, and concentrations of $\mathrm{Cu}$ in tissues of wild birds vary considerably within and among species and species groups; differences are not necessarily related to dietary intake but may be related to differences in excretion (Davis and Mertz 1987; Eisler 2000). A comparison of $\mathrm{Cu}$ concentrations in tissues of wild California condors with concentrations in other Accipitriformes and Falconiformes suggests that condors accumulate comparatively high levels of $\mathrm{Cu}$. The mean $\mathrm{Cu}$ concentration in livers of eight nestling California condors and 30 older, flighted birds was 255 and $70 \mathrm{mg} / \mathrm{kg}$ ww, respectively (B. Rideout, personal communication). Another study reported a mean hepatic $\mathrm{Cu}$ concentration in four flighted California condors of $41 \mu \mathrm{g} / \mathrm{g}$ ww (Wiemeyer et al. 1986). However, the mean liver $\mathrm{Cu}$ concentration in turkey vultures collected by shooting within California condor range was $7.1 \mu \mathrm{g} / \mathrm{g} \mathrm{ww}$, and the mean in turkey vultures dosed with $\mathrm{Cu}$ pellets was $20.5 \mu \mathrm{g} / \mathrm{g}$ ww (Wiemeyer et al. 1986; Risebrough et al. 2001). In other studies, the mean hepatic $\mathrm{Cu}$ concentration was approximately $20 \mu \mathrm{g} / \mathrm{g} \mathrm{dw}$ in peregrine falcons ( $F$. peregrinus) from Sweden, $4.2 \mu \mathrm{g} / \mathrm{g}$ ww (approximately $16 \mu \mathrm{g} / \mathrm{g} \mathrm{dw}$ based on stated moisture content of $74.4 \%$ ) in white-tailed eagles in Poland, and $17 \mu \mathrm{g} / \mathrm{g}$ and $43 \mu \mathrm{g} / \mathrm{g}$ dw in northern goshawks (Accipiter gentiles) and Japanese sparrowhawks (A. gularis), respectively, from Japan (Ek et al. 2004; Kalisińska et al. 2006; Horai et al. 2007). In Italy, the mean Cu concentration in livers of Eurasian kestrels ( $F$. tinnunculus) was approximately $25 \mu \mathrm{g} / \mathrm{g} \mathrm{dw}$ and ranged from approximately 15-22 $\mu \mathrm{g} / \mathrm{g} \mathrm{dw}$ in four species of hawks (Zaccaroni et al. 2008). Thus, reported $\mathrm{Cu}$ concentrations in livers of several wild hawks and falcons are similar to the levels we found in American kestrels dosed with $\mathrm{Cu}$ pellets.

In contrast to the aforementioned studies in raptors, some species of waterfowl have been reported to have high liver $\mathrm{Cu}$ concentrations, with evidence that male birds accumulate more than female birds. For example, mean concentrations of $\mathrm{Cu}$ in livers of common eiders (Somateria mollissima) collected in unpolluted areas of western Alaska were $607 \mu \mathrm{g} / \mathrm{g} \mathrm{dw}$ in male birds compared with $80 \mu \mathrm{g} / \mathrm{g} \mathrm{dw}$ in female birds, and common eider male birds in the Baltic Sea had mean hepatic $\mathrm{Cu}$ concentrations as high as $1381 \mu \mathrm{g} / \mathrm{g} \mathrm{dw}$, whereas the mean concentration in female birds was $43 \mu \mathrm{g} / \mathrm{g}$ dw (Franson et al. 2000; Stout et al. 2002). Another species of sea duck collected in Alaska, the Barrow's goldeneye (Bucephala islandica), had a mean of approximately $42 \mu \mathrm{g} / \mathrm{g}$ dw $\mathrm{Cu}$ in liver tissue, but there was no difference in concentrations between male and female birds (Franson et al. 1995). Perhaps the highest levels of $\mathrm{Cu}$ reported in birds have been in mute swans. Kobayashi et al. (1992) diagnosed $\mathrm{Cu}$ poisoning in several mute swans with a mean $\mathrm{Cu}$ concentration in liver tissue of $2150 \mathrm{mg} / \mathrm{kg} \mathrm{dw}$ compared with $200 \mathrm{mg} / \mathrm{kg} \mathrm{dw}$ in three swans that died at other locations. Molnar (1983) reported a mean hepatic $\mathrm{Cu}$ concentration of $3957 \mu \mathrm{g} / \mathrm{g}$ dw in three mute swans found dead or dying in New York, suggesting that the source of $\mathrm{Cu}$ was antifouling paint. Two captive mute swans used as controls had $64 \mu \mathrm{g} / \mathrm{g}$ and $121 \mu \mathrm{g} / \mathrm{g} \mathrm{dw}$ $\mathrm{Cu}$ in their livers (Molnar 1983). Mute swans sampled from an area in Denmark reported to be polluted with $\mathrm{Cu}$ had approximately $1096 \mathrm{mg} / \mathrm{kg}$ ww of $\mathrm{Cu}$ in their livers, more than twice as much as in swans from other areas of Denmark (Clausen and Wolstrup 1978).

Captive Canada geese diagnosed with $\mathrm{Cu}$ poisoning died within several hours of $\mathrm{Cu}$ sulfate application to the pond on which they were kept, exhibited necrosis of the proventricular and gizzard mucosa, and had hepatic $\mathrm{Cu}$ concentrations of $\leq 97 \mu \mathrm{g} / \mathrm{g}$ ww (Henderson and Winterfield 1975). Necrotic lesions similar to those seen in the dead Canada geese have also been reported in commercial poultry poisoned by $\mathrm{Cu}$ sulfate (Gilbert et al. 1996). When $\mathrm{Cu}$ salts are ingested in high concentrations during a short period of time, they function as protein coagulants, causing severe irritation of the alimentary mucosa, intravascular hemolysis, shock, and death (Blood and Henderson 1974). Frequent ingestion of small amounts of $\mathrm{Cu}$ salts typically causes no immediate toxic effects but results in an accumulation of $\mathrm{Cu}$ in the liver; if maximum hepatic concentrations are reached, $\mathrm{Cu}$ is released into the blood, and the animal dies from intravascular hemolysis (Blood and Henderson 1974). Our study as well as others with birds have not shown acute toxic effects of ingested metallic $\mathrm{Cu}$, and the fact that hepatic $\mathrm{Cu}$ concentrations increased little after repeated $\mathrm{Cu}$ exposure suggests that the physiological effects of metallic $\mathrm{Cu}$ are considerably different than those of $\mathrm{Cu}$ salts.

Metallothioneins are metal-binding proteins induced by various metals, including $\mathrm{Cu}$ (Cousins 1985). We hypothesized that metallothionein concentrations would be greater in American kestrels that received $\mathrm{Cu}$ than in controls, which was the case in male but not female birds. This may have been due in part to the fact that the magnitude of the difference in mean hepatic $\mathrm{Cu}$ concentrations between treated and control birds was greater in male than female birds, resulting in a correspondingly greater difference in metallothionein concentrations in male birds. A significant correlation between metallothionein and $\mathrm{Cu}$ concentrations in the liver, as we noted in kestrels, has previously been reported in other species of birds (Kojadinovic et al. 2007).

Apoptosis and acinar cell vacuolation of the pancreas are nonspecific histologic alterations that have been reported in experimental zinc exposure in Pekin ducklings and in cases of zinc toxicosis in captive and free-ranging wild birds (Kazacos and Van Vleet 1989; Droual et al. 1991; Sileo et al. 2004). The fact that these changes occurred in $25 \%$ of kestrels that received $\mathrm{Cu}$ suggests the 
possibility that they may be associated with $\mathrm{Cu}$ exposure. However, pancreatic changes also occurred in $20 \%$ of controls, and $\mathrm{Cu}$ concentrations in liver and kidney did not differ between birds with normal pancreas and those with apoptosis and vacuolation. When chickens were fed $\leq 4000 \mathrm{mg} \mathrm{Cu} / \mathrm{kg}$ of diet, the pancreas was unaffected, although the birds exhibited anorexia and gizzard lesions (Wight et al. 1986). Thus, the significance of the findings in kestrels is unclear. However, the absence of effects of $\mathrm{Cu}$ exposure on body mass, hematocrit, hemoglobin, methemoglobin, and plasma biochemistries indicates that under our study design, metallic $\mathrm{Cu}$ was not toxic to American kestrels. Retention time of pellets in the stomach of kestrels was of relatively short duration, and birds expected to regurgitate $\mathrm{Cu}$ fragments with a frequency similar to kestrels are not likely to be adversely affected by $\mathrm{Cu}$ ingestion. Although the findings in kestrels do not rule out the potential for $\mathrm{Cu}$ toxicity in species that might retain $\mathrm{Cu}$ fragments for a longer time, our results agree with previous experimental studies, adding to the evidence to date suggesting that $\mathrm{Cu}$ ammunition poses little threat of toxicity to birds. However, because the hepatic $\mathrm{Cu}$ concentrations in American kestrels administered $\mathrm{Cu}$ pellets were considerably less than concentrations found in wild California condors, kestrels may not be a good surrogate for condors, specifically, as Risebrough et al. (2001) suggested for turkey vultures.

Acknowledgments We thank Wayne Bauer and Mary Maxey for animal care, Sarah Warner for assistance with sample collection and processing, Glenn Olsen for assistance and consultation with radiography, Diana Goldberg for logistical support, and Daniel Finley for analysis of tissues for $\mathrm{Cu}$. Use of trade or product names does not imply endorsement by the United States Government.

\section{References}

Arizona Game and Fish Department (2009) Condors and lead. http://www.azgfd.gov/w_c/california_condor_lead.shtml/. Accessed 23 Mar 2011

Avery D, Watson RT (2009) Regulation of lead-based ammunition around the world. In: Watson RT, Fuller M, Pokras M, Hunt WG (eds) Ingestion of lead from spent ammunition: implications for wildlife and humans. The Peregrine Fund, Boise, ID, pp 161-168

Bannon DI, Parsons PJ, Centeno JA, Lal S, Xu H, Rosencrance AB et al (2011) Lead and copper in pigeons (Columbia livia) exposed to a small arms-range soil. Arch Environ Contam Toxicol 60:351-360

Bardo L, Bird DM (2009) The use of captive American kestrels (Falco sparverius) as wildlife models: a review. J Raptor Res 43:345-364

Bellrose FC (1965) The toxicity of ingested copper pellets in wild mallards. In: Wasted Waterfowl, Report by the Mississippi Flyway Council Planning Committee, pp 70-72

Blood DC, Henderson JA (1974) Veterinary medicine, 4th edn. Williams and Wilkins, Baltimore, MD
Clausen B, Wolstrup C (1978) Copper load in mute swans (Cygnus olor) found in Denmark. Nord Vet Med 30:260-266

Cousins RJ (1985) Absorption, transport, and hepatic metabolism of copper and zinc: special reference to metallothionein and ceruloplasmin. Physiol Rev 65:238-309

Craig TH, Connelly JW, Craig EH, Parker TL (1990) Lead concentrations in golden and bald eagles. Wilson Bull 102: $130-133$

Craighead D, Bedrosian B (2008) Blood lead levels of common ravens with access to big-game offal. J Wildl Manage 72: 240-245

Davis GK, Mertz W (1987) Copper. In: Mertz W (ed) Trace elements in human and animal nutrition, vol 1, 5th edn. Academic Press, San Diego, CA, pp 301-364

Droual R, Meteyer CU, Galey FD (1991) Zinc toxicosis due to ingestion of a penny in a gray-headed chachalaca (Ortalis cinereiceps). Avian Dis 35:1007-1011

Dunn MA, Blalock TL, Cousins RJ (1987) Metallothionein (42525A). Proc Soc Exp Biol Med 185:107-119

Eisler R (2000) Handbook of chemical risk assessment: health hazards to humans, plants, and animals, vol 1: metals. Lewis, Boca Raton, FL

Ek KH, Morrison GM, Lindberg P, Rauch S (2004) Comparative tissue distribution of metals in birds in Sweden using ICP-MS and laser ablation ICP-MS. Arch Environ Contam Toxicol 47: 259-269

Fairbanks VF, Klee GG (1987) Biochemical aspects of hematology. In: Tietz NW (ed) Fundamentals of clinical chemistry. Saunders, New York, NY, pp 789-824

Ford S (2010) Raptor gastroenterology. J Exotic Pet Med 19:140-150

Franson JC, Koehl PS, Derksen DV, Rothe TC, Bunck CM, Moore JF (1995) Heavy metals in seaducks and mussels from Misty Fjords National Monument in Southeast Alaska. Environ Monit Assess $36: 149-167$

Franson JC, Hollmén T, Poppenga RH, Hario M, Kilpi M (2000) Metals and trace elements in tissues of common eiders (Somateria mollissima) from the Finnish archipelago. Ornis Fenn 77:57-63

Friend M, Franson JC, Anderson WL (2009) Biological and societal dimensions of lead poisoning in birds in the USA. In: Watson RT, Fuller M, Pokras M, Hunt WG (eds) Ingestion of lead from spent ammunition: implications for wildlife and humans. The Peregrine Fund, Boise, ID, pp 34-60

Gilbert RW, Sander JE, Brown TP (1996) Copper sulfate toxicosis in commercial laying hens. Avian Dis 40:236-239

Gill CE, Langelier KM (1994) Acute lead poisoning in a bald eagle secondary to bullet ingestion. Can Vet J 35:303-304

Helander B, Axelsson J, Borg H, Holm K, Bignert A (2009) Ingestion of lead from ammunition and lead concentrations in white-tailed sea eagles (Haliaeetus albicilla) in Sweden. Sci Total Environ 407:5555-5563

Henderson BM, Winterfield RW (1975) Acute copper toxicosis in the Canada goose. Avian Dis 19:385-387

Horai S, Watanabe I, Takada H, Iwamizu Y, Hayashi T, Tanabe S et al (2007) Trace element accumulations in 13 avian species collected from the Kanto area, Japan. Sci Total Environ 373: $512-525$

Hunt WG, Burnham W, Parish CN, Burnham KK, Mutch B, Oaks JL (2006) Bullets fragments in deer remains: implications for lead exposure in avian scavengers. Wildl Soc Bull 34:167-170

Hunt WG, Parish CN, Farry SC, Lord TG, Sieg R (2007) Movements of introduced California condors in Arizona in relation to lead exposure. In: Mee A, Hall LS (eds) California condors in the 21 st century. Nuttall Ornithological Club, Cambridge, MA and The American Ornithologists' Union, Washington DC, pp 79-96 
Irby HD, Locke LN, Bagley GE (1967) Relative toxicity of lead and selected substitute shot types to game farm mallards. J Wildl Manage 31:253-257

Iwata H, Watanabe M, Kim EY, Gotoh R, Yasunaga G, Tanabe S et al (2000) Contamination by chlorinated hydrocarbons and lead in Steller's sea eagle and white-tailed sea eagle from Hokkaido, Japan. In: Ueta M, McGrady MJ (eds) First symposium on Steller's and white-tailed sea eagles in East Asia. Wild Bird Society of Japan, Tokyo, Japan, pp 91-106

Kalisińska E, Salicki W, Jackowski A (2006) Six trace metals in white-tailed eagle from northwestern Poland. Pol J Environ Stud 15:727-737

Kazacos EA, Van Vleet JF (1989) Sequential ultrastructural changes of the pancreas in zinc toxicosis in ducklings. Am J Pathol 134:581-595

Knott J, Gilbert J, Green RE, Hoccom DG (2009) Comparison of the lethality of lead and copper bullets in deer control operations to reduce incidental lead poisoning; field trials in England and Scotland. Conserv Evidence 6:71-78

Knott J, Gilbert J, Hoccom DG, Green RE (2010) Implications for wildlife and humans of dietary exposure to lead from fragments of lead rifle bullets in deer shot in the UK. Sci Total Environ 409:95-99

Kobayashi Y, Shimada A, Umemura T, Nagai T (1992) An outbreak of copper poisoning in mute swans (Cygnus olor). J Vet Med Sci 54:229-233

Kojadinovic J, Bustamante P, Le Corre M, Cosson RP (2007) Trace elements in three marine birds breeding on Reunion Island (Western Indian Ocean): part 2 - factors influencing their detoxification. Arch Environ Contam Toxicol 52:431-440

Krone O, Kenntner N, Trinogga A, Nadjafzadeh M, Scholz F, Sulawa J et al (2009) Lead poisoning in white-tailed sea eagles: causes and approaches to solutions in Germany. In: Watson RT, Fuller M, Pokras M, Hunt WG (eds) Ingestion of lead from spent ammunition: implications for wildlife and humans. The Peregrine Fund, Boise, ID, pp 289-301

Locke LN, Irby HD, Bagley GE (1967) Histopathology of mallards dosed with lead and selected substitute shot. Bull Wildl Dis Assoc 3:143-147

Molnar JJ (1983) Copper storage in the liver of the wild mute swan (Cygnus olor). Arch Pathol Lab Med 107:629-632

National Research Council (1977) Copper: medical and biological effects of environmental pollutants. National Academy of Sciences, Washington, DC

Neumann K (2009) Bald eagle lead poisoning in winter. In: Watson RT, Fuller M, Pokras M, Hunt WG (eds) Ingestion of lead from spent ammunition: implications for wildlife and humans. The Peregrine Fund, Boise, ID, pp 210-218

Oltrogge V (2009) Success in developing lead-free, expanding-nose centerfire bullets. In: Watson RT, Fuller M, Pokras M, Hunt WG (eds) Ingestion of lead from spent ammunition: implications for wildlife and humans. The Peregrine Fund, Boise, ID, pp 310-315

Pain DJ, Bavoux C, Burneleau G (1997) Seasonal blood lead concentrations in marsh harriers Circus aeruginosus from
Charente-Maritime, France: relationship with the hunting season. Biol Conserv 81:1-7

Pain DJ, Fisher IJ, Thomas VG (2009) A global update of lead poisoning in terrestrial birds from ammunition sources. In: Watson RT, Fuller M, Pokras M, Hunt WG (eds) Ingestion of lead from spent ammunition: implications for wildlife and humans. The Peregrine Fund, Boise, ID, pp 99-118

Pattee OH, Carpenter JW, Frits SH, Rattner BA, Wiemeyer SN, Royle JA et al (2006) Lead poisoning in captive Andean condors (Vultur gryphus). J Wildl Dis 42:772-779

Rattner BA, Franson JC, Sheffield SR, Goddard CI, Leonard NJ, Stang D et al (2008) Sources and implications of lead ammunition and fishing tackle on natural resources. Wildlife Society Technical Review 08-01. The Wildlife Society, Bethesda, MD

Risebrough RW, Valencia R, Clendenen D, Mason AZ, Bloom PH, Wallace MP et al (2001) Absence of demonstrable toxicity to turkey vultures, Cathartes aura of copper and tungsten-tinbismuth-composite pellets. Final Report to US Fish and Wildlife Service, California Condor Recovery Program. The Bodega Bay Institute, Berkeley, CA

Rorabacher DB (1991) Statistical treatment for rejection of deviant values: critical values of Dixon's " $Q$ " parameter and related subrange ratios at the $95 \%$ confidence level. Anal Chem 63:139-146

Scheuhammer AM, Cherian MG (1991) Quantification of metallothionein by silver saturation. Methods Enzymol 205:78-83

Sileo L, Beyer WN, Mateo R (2004) Pancreatitis in wild zincpoisoned waterfowl. Avian Pathol 32:655-660

Stout JH, Trust KA, Cochrane JF, Suydam RS, Quakenbush LT (2002) Environmental contaminants in four eider species from Alaska and arctic Russia. Environ Pollut 119:215-226

Thomas VG, McGill IR (2008) Dissolution of copper, tin, and iron from sintered tungsten-bronze spheres in a simulated avian gizzard, and an assessment of their potential toxicity to birds. Sci Total Environ 394:283-289

United States Fish and Wildlife Service (2009) Migratory bird hunting; approval of tungsten-iron-fluoropolymer shot alloys as nontoxic for hunting waterfowl and coots; availability of draft environmental assessment. Fed Reg 74:39598-39604

Wiemeyer SN, Jurek RM, Moore JF (1986) Environmental contaminants in surrogates, foods, and feathers of California condors (Gymnogyps californianus). Environ Monit Assess 6:91-111

Wiemeyer SN, Scott JM, Anderson MP, Bloom PH, Stafford CJ (1988) Environmental contaminants in California condors. J Wildl Manage 52:238-247

Wight PAL, Dewar WA, Saunderson CL (1986) Zinc toxicity in the fowl: ultrastructural pathology and relationship to selenium, lead and copper. Avian Pathol 15:23-38

Zaccaroni A, Andreani G, Ferrante MC, Carpenè E, Isani G, Lucisano A (2008) Metal concentrations in the liver and kidney of raptor species from the Calabria region, Italy. Acta Vet (Beograd) $58: 315-324$ 